\title{
Measuring the effectiveness of Individual assessment methods in Collaborative/ Cooperative activity in online teaching
}

\author{
Dr.D.Kavitha $^{1}$,Dr.D.Anitha ${ }^{2}$ \\ ${ }^{1}$ Assistant Professor, Department of Electrical and Electronics Engineering, Thiagarajar College of Engineering, Madurai \\ ${ }^{2}$ Assistant Professor, Dept. of Applied Mathematics and Computational Science, Thiagarajar College of Engineering, \\ Madurai \\ 11kavitha@tce.edu \\ 2anithad@tce.edu
}

\begin{abstract}
Assessment of collaborative activities comprises two important elements: group assessment and individual assessment. This research study explores specific methods for assessing the individual students in online collaborative/cooperative activity and analyzes the efficiency in terms of student learning. An online collaborative activity based on the Student Groups Achievement Division (STAD) method has been planned and implemented for the undergraduate third semester Engineering students $(n=71)$. The activity has been designed in such a way that the students perform the activity through the collaborative features of the Learning Management Systems (LMS) such as group projects and discussions. Group assessment is measured with discussions and group report writing while the individual assessment is measured through quizzes, tests and activity journals. The scores for the quiz and activity journal are taken into account to measure the student learning. These scores are compared against their performance scores in the summative examination. From the observations by comparing the scores, it is found that these strategies measure the individual learning effectively such that they fall in linear with the formal examination marks. Also, feedback is obtained from the students to ensure their satisfaction in individual assessment. Success index for the activity based on students' feedback is calculated using weighted likert scale and found to be 0.811 (Ideal index =1) which is an appreciable score.
\end{abstract}

\section{Keywords:}

Online teaching, Collaborative activity, Cooperative activity, Assessment, Outcomes

\section{Introduction}

Indian Technical education system, with its educational Board "The National Board of Accreditation (NBA)", has introduced new processes, parameters and criteria for accreditation. These are in line with the best international practices and oriented to assess the outcomes of the programme. To achieve the outcomes effectively, the technical institutions are moving towards student centric education from teacher centric education. Many active learning and collaborative learning methods have been introduced and practiced. In Particular, Collaborative/Cooperative activities are often required to improve graduate attributes. There are lot of Collaborative learning methods including Jigsaw, Student-GroupsAchievement-Division (STAD), Team Group Tournament (TGT), Project Based Learning (PBL). The conduct and assessment of such activities online is a tedious and tough task. Specific online platforms have to be identified for carrying out collaborative activities and online assessments are required to be formulated for collaborative activities with much care. While group assessment is easier by assessing the resultant product of the group activity with an evaluation rubric, assessing the individual performance in a group activity turns out to be a tougher task. There is a need for finding effective methods to ensure the individual learning of the students. When certain methods are claimed as effective by teachers, it is not regarded so by the students (Anitha et al. 2020). Hence there is a need of performance measurements that show the effectiveness of any teaching learning strategy.

Collaborative and cooperative learning could be seen as synonymous student centric approaches (Jacobs, G. M, 2015) and that teachers and students, regardless of which of the two terms they use, should and will vary the ways they shape their learning environments in order to facilitate the cognitive and affective benefits that studentstudent interaction offers. Implementing such learning in online mode could be a difficult task due to its conduct and assessment. It is claimed that current emphasis on the benefits of collaborative learning disparages the importance of individual learning processes and reduces the opportunities to assess individual learning (Yadin, A and Or-Bach, R, 2019). According to this research, specially designed individual assignments can reduce the failure rate in courses. A work done by the authors (Kavitha \& Anitha, 2018) in a microcontroller course has declared that collaborative learning through projects lead to an overall performance improvement in groups. However, they have declared that an individual assessment plan is crucial is such activity.

Another research work has stated that group work is only invented to reduce grading time and group work certainly has a positive effect on student satisfaction (Opdecam, E., and Everaert, P, 2018). Teacher's Experiences in Teaching 
with STAD Technique from its introduction in 2005 up to 2015 (Yusuf et al. 2015) have been reviewed and evolvement of STAD in measuring student outcomes have been explored. From the existing literature study, the individual assessment in a group activity is still a change and needs more research in this arena.

In this work, the challenge is undertaken. A set of individual and group assessments have been proposed and the effectiveness of individual and group assessment in collaborative learning is studied. STAD is used for the study. The assessments are designed so that the graduate attributes are mapped with the outcomes and are suitably measured using appropriate rubrics. The result of the assessments have been analyzed to verify whether the individual and group assessments are effective in terms of student performance.

\section{Research Questions}

The following research questions have been formulated for the research.

1. How effective are the individual and group assessment methods in Collaborative/cooperative activities?

2. What is the impact of the individual assessment methods of Collaborative activities in the academic performance?

3. Is it possible to measure graduate attributes through these activities?

\section{Methodology and Materials}

The activity chosen for this research is STAD - Student Groups-Achievement Divisions. This research study has used quantitative and qualitative analysis with the student scores and feedback survey respectively. This research study has been implemented in a UG class for a course "18EE340- Digital Systems " with 71 students. The course is offered to the third semester Electrical and Electronics Engineering students of Thiagarajar College of Engineering, an autonomous institution in Madurai, India. Concept taught through collaborative activity: Design and Analysis of synchronous sequential circuits in the course 18EE340- Digital Systems offered to the students of second year EEE students.

Objective of the activity: At the end of the activity, the students will be able to

1. Design synchronous sequential circuit for the given specifications (Bloom's level : Apply)

2. Generate the state table and state diagram of the given sequential circuit (Bloom's level : Apply)

The scores obtained by the students in their previous assessments were considered to make the groups. The average marks of the group members should be between $55 \%$ and $75 \%$. This strategy restricts group formulation with all members having below average marks. Similarly the strategy restricts group formulation with all top performing students. Students grouped themselves according to the marks they obtained satisfying the constraints.

This activity spans over the time period of 10 days including holidays and the details of the activity is provided in Table 1.

Table 1: Details of proposed Implementation of STAD

\begin{tabular}{|c|c|}
\hline Day & Activity \\
\hline 1 & $\begin{array}{l}\text { The rules/constraints to be followed by each group are } \\
\text { specified. Assessment methods are described along with } \\
\text { rubrics. Concept of generating synchronous sequential } \\
\text { circuits is taught in the class. In Online synchronous } \\
\text { lecture, excitation table and design are taught. } 1 \\
\text { homework problem is given. The procedure for designing } \\
\text { the synchronous counters is provided as a video and given } \\
\text { to the students for revision/self learning. }\end{array}$ \\
\hline 2 & $\begin{array}{l}\text { Discussion on homework problem in synchronous lecture } \\
\text { class. 1design example is done inside the class as a group } \\
\text { activity in break out rooms.State table is verified in virtual } \\
\text { lab - https://logic.ly/demo. } \\
\text { A simple quiz is posted to assess their synchronous class } \\
\text { learning }\end{array}$ \\
\hline 3 & $\begin{array}{l}12 \text { synchronous sequential problems from various digital } \\
\text { books (book back and worked examples) and old question } \\
\text { papers are taken and given to the students through Canvas } \\
\text { Instructure. } \\
\text { Students are instructed to work as a group towards these } \\
\text { problems. Frequency of solving: } 3 / \text { day. } \\
\text { Asynchronous group activity (Day 1) : Students } \\
\text { discussed in group and solved any } 3 \text { problems. Some } \\
\text { group students had shorter discussions on group and fix } \\
\text { individual works to complete the task of the day. Some } \\
\text { did group discussions through video conferencing tools, } \\
\text { social networks, learning management system etc. }\end{array}$ \\
\hline 4 & $\begin{array}{l}\text { Regular synchronous online Class on next topic is started } \\
\text { in which Last } 15 \text { minutes is given for discussion }- \\
\text { regarding the day } 1 \text { solved problems and address day } 2 \\
\text { problems (next 3). Asynchronous group activity (Day } \\
\text { 2) :Students will discuss in group and solve any next } 3 \\
\text { problems. } \\
\text { Graded discussion-1 is created on canvas Instructure } \\
\text { (LMS). Students as a group need to post the problems } \\
\text { numbers they have addressed in their group. Along with } \\
\text { that, individual contribution (roles and responsibilities), } \\
\text { difficulties faced, code of conduct are to be mentioned in } \\
\text { the graded discussion. Suggestions for improvement are } \\
\text { also asked. Thus in this graded discussion complete group } \\
\text { activity log should be provided by the group leader for } 2 \\
\text { passed days. }\end{array}$ \\
\hline 5 & $\begin{array}{l}\text { Interim formative individual assessment: Quiz is } \\
\text { launched in canvas instructure. } \\
\text { Last } 15 \text { minutes of synchronous online class: group } \\
\text { discussion - Regarding the solved problems and address } \\
\text { next } 3 \text { problems } \\
\text { Out of class group activity: (Day 3)Students discussed in } \\
\text { group and solve any next } 3 \text { problems. }\end{array}$ \\
\hline 6 & $\begin{array}{l}\text { Online class is taken on next topic. } \\
\text { Last } 15 \text { minutes: group discussion - regarding the solved } \\
\text { problems and address remaining } 3 \text { problems. } \\
\text { Out of class group activity: (Day 4) Students will discuss } \\
\text { in group and solve the remaining } 3 \text { problems. }\end{array}$ \\
\hline $\begin{array}{l}7 \& \\
8\end{array}$ & Extra two days to complete the pending works. \\
\hline 9 & $\begin{array}{l}\text { Students are asked to submit their individual journal } \\
\text { related to the activity as well as group report } \\
\text { submission. The rubrics for assessment is shared initially. } \\
\text { Journal assessment is for } 20 \text { marks and converted to } 50 \\
\text { for analysis. }\end{array}$ \\
\hline
\end{tabular}


\begin{tabular}{|l|l|}
\hline 10 & $\begin{array}{l}\text { Individual assessment through quiz: Quiz on the chosen } \\
\text { topic testing the concepts learnt in the group activity. The } \\
\text { questions are of apply type. 20 questions are posted and } \\
\text { final mark is converted to 50. }\end{array}$
\end{tabular}

The marks scored by the students in individual assessment through quiz, marks scored in Journal writing, marks scored in group report submission are taken from the collaborative activity for quantitative analysis. These marks are compared against the summative test marks which addresses the same outcome. A dependent two tailed T- test is proposed for analysis as it is a statistical procedure used to determine whether the mean difference between two sets of observations is zero.

After publishing all the marks to the students, a feedback regarding the activity is collected from the students. This student feedback is collected via Google forms. The general questions asked in the feedback are as follows:

Q1. I can explain the concepts of synchronous sequential circuits to others

Q2. Out of class activities contributed to my learning

Q3. I can apply the concepts in future

Q4. I am able to obtain the state table for the given specification.

Q5. I can work with Digital based complex systems

Q6. I enjoy all the activities of Collaborative learning

Q7. Collaboration is very useful for learning

Q8. Time is sufficient for out of class activity

Q9. Time is sufficient for in-class activity

Q10. I like to have more Collaborative learning in future.

At the end, open feedback question asking for suggestions is also provided. Difficulty of students if any, are also obtained from feedback survey. The student name is optional.

The above questionnaire is provided in likert scale with 5 scales such as Strongly agree, agree, neutral, disagree and strongly disagree. The weightage $\left(\mathrm{w}_{\mathrm{j}}\right)$ assigned for likert scales are 5,4,3,1,0 respectively. (Kavitha, D and Anitha, D. 2016). The feedback results are used to perform a qualitative analysis of this research study. The student satisfaction index is calculated from the results of this survey. Success index of the activity is calculated as below: SI

$=\sum_{i=1}^{N Q} \sum_{j=1}^{N S} \frac{\text { Number of students with } j \text { th response for ith question } X W_{j}}{\text { Totudents } X \text { Number of questions } X \text { Maximum weightage }}$

(1)

Where, NQ-Number of questions in likert scale (10 here)

NS- Number of scale (5 here)

$\mathrm{Wj}$ - Weightage of jth scale.

Ideal SI value is 1 which is the possible highest score and the worst score is 0 which makes the range of SI between 0 to 1 .

Also, the rubrics are compared against the various graduate attributes which are mentioned as program outcomes (PO) in curriculum as follows:

PO1 Engineering knowledge

PO2 Problem analysis

PO3 Design/development of solutions
PO4 Conduct investigations of complex problems

PO5 Modern tool usage

PO6 The engineer and society

PO7 Environment and sustainability

PO8 Ethics

PO9 Individual and group work

PO10 Communication

PO11 Project management and finance

PO12 Life-long learning

The first four POs are directly checked in the individual assessment.

Including the individual components of assessment in rubrics would help analysing the performance at a micro level (Anitha D et al, 2018). Following the same, Rubrics for Evaluating Journal writing and its mapping to POs are given in table 2 .

Table 2: Rubrics for Journal writing and its mapping to POs

\begin{tabular}{|l|l|l|l|}
\hline S.NO & Parameters & $\begin{array}{l}\text { PO } \\
\text { addressed }\end{array}$ & $\begin{array}{l}\text { Marks } \\
\text { given }\end{array}$ \\
\hline 1 & $\begin{array}{l}\text { Periodic update of journal } \\
\text { with date }\end{array}$ & PO10 & 5 \\
\hline 2 & $\begin{array}{l}\text { Work done and } \\
\text { responsibilities taken }\end{array}$ & PO9 & 6 \\
\hline 3 & $\begin{array}{l}\text { Own reflections without } \\
\text { plagiarism PO8 }\end{array}$ & 7 \\
\hline 4 & $\begin{array}{l}\text { Clear write up without } \\
\text { grammar mistakes }\end{array}$ & PO10 & 2 \\
\hline
\end{tabular}

Attainment of PO with respect to the journal writing is obtained from the following equation

$\mathrm{PO}_{k}(\%)=$ Mean Marks in respective parameter/Maximum

Marks in respective parameter $* 100$

where k represents the addressed PO.

Similarly for group report submission, rubrics are based on timely submission, Solution to problems and group reflection. In group report submission, all members in the group are given equal marks. The mapping of survey questions (Q1 to Q10) with POs is provided in table 3.

Table 3: Mapping of Survey questions with PO

\begin{tabular}{|l|l|l|}
\hline S.No & Question number & PO addressed \\
\hline 1 & Q1, Q2, Q3 & PO1 \\
\hline 2 & Q4 & PO2 \\
\hline 3 & Q5 & PO3 \\
\hline 4 & Q6, Q7 & PO9 \\
\hline 5 & Q8,Q9 & PO11 \\
\hline 6 & Q10 & PO10 \\
\hline
\end{tabular}

Calculation of Attainment of PO through survey is done using the following formulae,

$=\sum_{j=1}^{P O_{k}} \frac{\text { Number of students with jth response for ith question } X W_{j}}{\text { Total students } X \text { Maximum weightage }} X 100$

(3)

Where,

NS- Number of scale (5 here)

$\mathrm{Wj}$ - Weightage of jth scale.

k- PO addressed 


\section{Implementation}

The group details along with their group average marks are received through Learning Management System (LMS) Canvas Instructure. 17 groups are created. Out of 71 students, 66 have participated in this experiment. Figure 1 describes the various assessment components of the activity along with the marks allotted for each component. The activity is conducted as described in the table 1 .

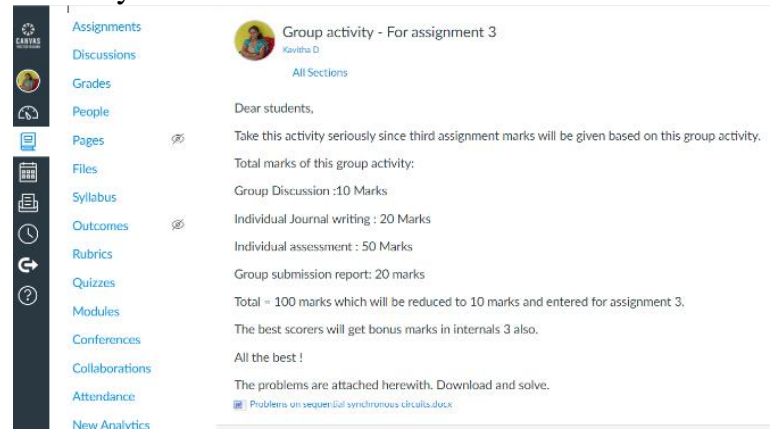

Fig 1: Marks split up of the STAD activity

\section{Results and Discussions}

Each group has 4 or 5 members and totally 17 groups are created and participated. The group members marks are averaged to determine the group mark. Table 4 mention the group score obtained by each group and Figure 2 illustrate the scores graphically.

\begin{tabular}{|c|c|c|c|}
\hline $\begin{array}{l}\text { Group } \\
\text { Number }\end{array}$ & $\begin{array}{l}\text { Number } \\
\text { of } \\
\text { students }\end{array}$ & $\begin{array}{l}\text { Group } \begin{array}{l}\text { Score } \\
\text { (Median }\end{array} \text { Score } \\
=60.25 \%)\end{array}$ & $\begin{array}{l}\text { Group } \\
\text { Performed } \\
\text { less than } \\
\text { median score } \\
\text { (yes/no) }\end{array}$ \\
\hline 1 & 4 & 55.67 & YES \\
\hline 2 & 3 & 80.44 & $\mathrm{NO}$ \\
\hline 3 & 4 & 83.33 & $\mathrm{NO}$ \\
\hline 4 & 3 & 79.55 & $\mathrm{NO}$ \\
\hline 5 & 4 & 87.33 & $\mathrm{NO}$ \\
\hline 6 & 4 & 74 & $\mathrm{NO}$ \\
\hline 7 & 4 & 69.33 & $\mathrm{NO}$ \\
\hline 8 & 4 & 71.33 & $\mathrm{NO}$ \\
\hline 9 & 4 & 67.33 & $\mathrm{NO}$ \\
\hline 10 & 4 & 54 & YES \\
\hline 11 & 3 & 39.33 & YES \\
\hline 12 & 5 & 34.67 & YES \\
\hline 13 & 4 & 66.67 & $\mathrm{NO}$ \\
\hline 14 & 4 & 27 & YES \\
\hline 15 & 4 & 34 & YES \\
\hline 16 & 4 & 44.67 & YES \\
\hline 17 & 4 & 55.67 & YES \\
\hline
\end{tabular}

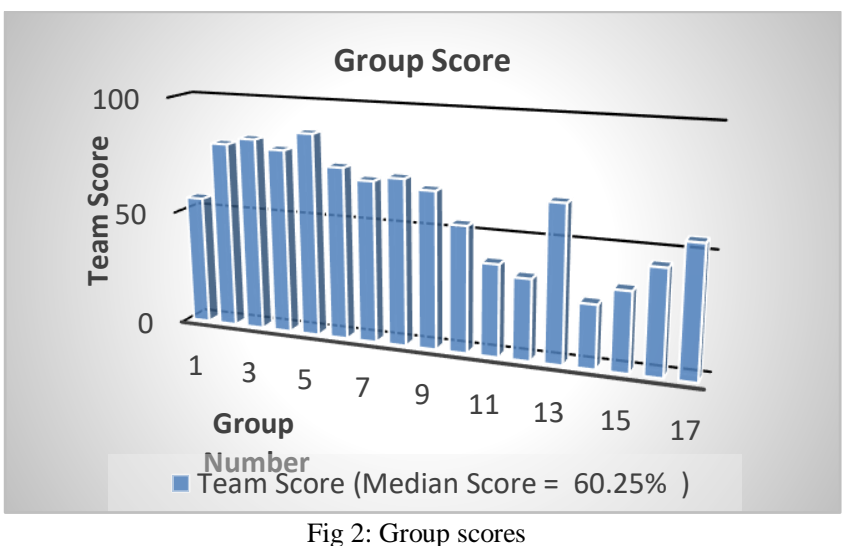

Some reasons for the good performance of the group includes the following:

1. Highly participative and apply some strategy immediately when found deadlock.

2. Some toppers made the group participative and lead the group effectively and took responsibility for knowledge transfer.

3. Some above average students connect with the teacher frequently to clarify their doubts.

4. Students show interest to open the dead lock in minimum time.

Out of 66 participated students, 34 students participated in the survey. The result of the survey is given in figure 3 .

SI for the above values which is calculated from the equation 1 is 0.811 . The score seems to be satisfactory.

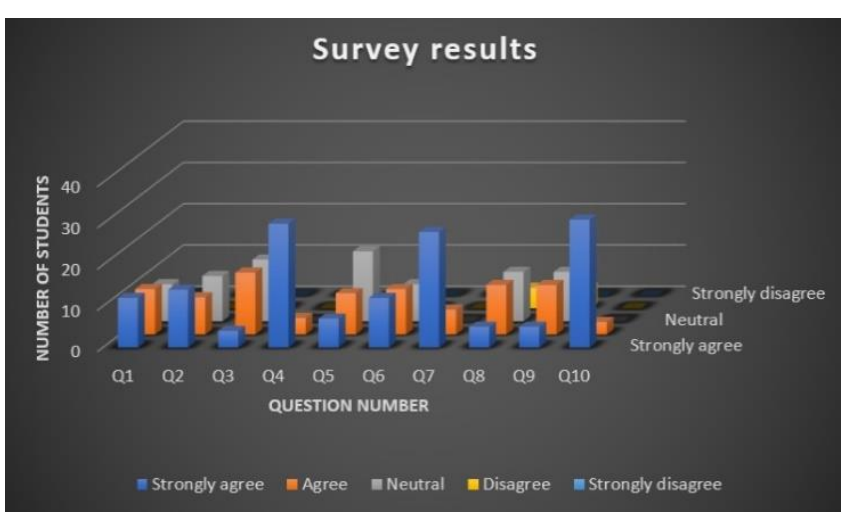

Fig 3: Survey results.

To test the impact of group and individual activities of collaborative activity with respect to the performance of students in summative assessment, the following activities conducted in STAD are taken

Activity 1: Individual assessment through Quiz in STAD

Activity 2: Journal submission evaluated using rubrics in STAD

Activity 3: Group submission in STAD (Equal marks given to all members of the group)

The activity scores of each student is compared with the respective summative test score. As the scores of the same students are to be tested, a 2 tail T-test was conducted between the samples. After the pre processing of data for 
validity check, the samples taken for the test $=52$. The test is performed for the significance level of 0.05 .

The results are given in table 5 where SD is standard deviation.

Table 5: $\mathbf{T}$ - Test results

\begin{tabular}{|l|l|l|l|l|l|}
\hline $\begin{array}{l}\text { S.N } \\
\text { o }\end{array}$ & $\begin{array}{l}\text { Data1 } \\
\text { (Collaborat } \\
\text { ive activity) }\end{array}$ & $\begin{array}{l}\text { Data2 } \\
\text { (Session } \\
\text { test) }\end{array}$ & SD & $\begin{array}{l}\text { T- } \\
\text { Valu } \\
\text { e }\end{array}$ & Result \\
\hline 1 & Activity1 & $\begin{array}{l}\text { Summati } \\
\text { ve }\end{array}$ & $\begin{array}{l}5.9 \\
5\end{array}$ & -1.56 & $\begin{array}{l}\text { Not } \\
\text { significat }\end{array}$ \\
\hline 2 & Activity2 & $\begin{array}{l}\text { Summati } \\
\text { ve }\end{array}$ & $\begin{array}{l}2.0 \\
2\end{array}$ & -2.00 & $\begin{array}{l}\text { Not signific } \\
\text { ant }\end{array}$ \\
\hline 3 & Activity3 & $\begin{array}{l}\text { Summati } \\
\text { ve }\end{array}$ & $\begin{array}{l}1.7 \\
7\end{array}$ & -8.44 & Significant \\
\hline
\end{tabular}

The test results show that there is no significant difference in the summative assessment when tested against STAD quiz activity and journal writing. Hence, it is clear that these activities are proportional to the summative marks. At the same time, when group report submission marks are tested against summative assessment, it shows significant difference concluding that the group report submission marks does not have direct relation with student learning. The attempt of calculating the graduate attributes through these activities is also done. Table 6 provides the attainment calculation of specific POs addressed by journal writing which is calculated using equation 2 .

Table 6: Percentage of PO attained with respect to Journal

\begin{tabular}{|l|l|l|l|l|}
\hline $\begin{array}{l}\text { S. } \\
\mathbf{N} \\
\mathbf{O}\end{array}$ & Parameters & $\begin{array}{l}\text { PO } \\
\text { addr } \\
\text { essed }\end{array}$ & $\begin{array}{l}\text { Average } \\
\text { Marks } \\
\text { obtained }\end{array}$ & $\begin{array}{l}\text { Attainm } \\
\text { ent } \\
(\%)\end{array}$ \\
\hline 1 & $\begin{array}{l}\text { Periodic update of } \\
\text { journal with date }\end{array}$ & PO10 & 4.5 & 90 \\
\hline 2 & $\begin{array}{l}\text { Work done and } \\
\text { responsibilities } \\
\text { taken }\end{array}$ & PO9 & 5 & 83.33 \\
\hline 3 & $\begin{array}{l}\text { Own reflections } \\
\text { without plagiarism }\end{array}$ & PO8 & 4 & 57.14 \\
\hline 4 & $\begin{array}{l}\text { Clear write up } \\
\text { without grammar } \\
\text { mistakes }\end{array}$ & PO10 & 1.5 & 75 \\
\hline
\end{tabular}

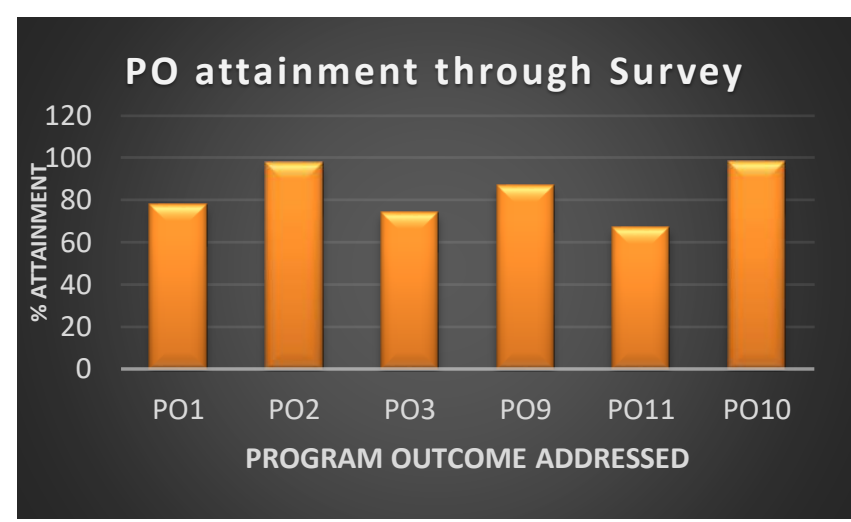

Fig 4: PO attainment through Survey

Survey questions are mapped with POs in table 3and the attainment of POs through survey is calculated using equation 3 . The results of PO attainment through survey which is obtained using the equation 3 is given in figure 4 . From Table 6 and Figure 4, it is clear that the individual assessment methods lead to a satisfactory performance in the Program Outcomes.

\section{Conclusion}

This research study explores specific methods for assessing the individual students in online collaborative/cooperative activity and analyzes the efficiency in terms of student learning. This is done by considering various assessment methodologies in STAD. The activity has been designed in such a way that the students perform the activity through the collaborative features of the Learning Management System (LMS) such as group projects and discussions.

The scores for the quiz and activity journal are taken into account to measure the student learning. These scores are compared against their performance scores in the summative examination. From the observations by comparing the scores, it is found that these strategies measure the individual learning effectively such that they have significat impact with the formal examination marks. Also, feedback is obtained from the students to ensure their satisfaction in individual assessment. Success index for the activity based on students' feedback is calculated using weighted likert scale and found to be 0.811 (Ideal index $=1$ ) which is an appreciable score. It is also interestingly noted that graduate attributes can also be measured using these activities.

\section{References}

Anitha, D., Jeyamala, C., \& Kavitha, D. (2018). Assessing and Enhancing Creativity in a Laboratory Course with Project Based Learning. Journal of Engineering Education Transformations, 32(2), 2349-2473.

Anitha, D., Kavitha, D., Prakash, R. R., \& Raja, S. C. (2020). Identification of Opinion Difference in Teaching Learning Methods and Recommendation to Faculty. Journal of Engineering Education Transformations, 33, 421-424.

Jacobs, G. M. (2015). Collaborative Learning or Cooperative Learning? The Name Is Not Important; Flexibility Is. Online Submission, 3(1), 32-52.

Kavitha, D., \& Anitha, D. (2016, December). Project Based Learning Using ICT Tools to Achieve Outcomes for the Course'Microcontrollers Based System Design': A Case Study. In 2016 IEEE 4th International Conference on MOOCs, Innovation and Technology in Education (MITE) (pp. 223-228). IEEE.

Kavitha, D., \& Anitha, D. (2018). Flipped Classroom Using ICT Tools to Improve Outcome for the Course'Soft Computing'-A Case Study. Journal of Engineering Education Transformations, 32(2), 2349-2473.

Opdecam, E., \& Everaert, P. (2018). Seven disagreements about cooperative learning. Accounting Education, 27(3), 223-233.

Yadin, A., \& Or-Bach, R. (2019). The importance of emphasizing individual learning in the "collaborative learning era". Journal of Information Systems Education, 21(2), 5.

Yusuf, Y. Q., Natsir, Y., \& Hanum, L. (2015). A Teacher's Experience in Teaching with Student Teams-Achievement Division (STAD) Technique. International Journal of Instruction, 8(2), 99-112.

\section{Corresponding Author}

Dr. D. Kavitha, Assistant Professor, Thiagarajar College of Engineering. 